\title{
SEED GERMINATION BEHAVIOUR, SEEDLING GROWTH, MORPHO- PHYSIOLOGICAL AND YIELD ATTRIBUTES OF RICE GROWN IN CADMIUM-ADDED SOIL
}

\author{
M. Zahidul Islam Hawlader TUHIN, Taufika Islam ANEE, Naznin AHMED, Mira RAHMAN, \\ Khussboo RAHMAN, Mirza HASANUZZAMAN \\ Department of Agronomy, Faculty of Agriculture, Sher-e-Bangla Agricultural University, Dhaka-1207, Bangladesh \\ e-mail:mhzsauag@yahoo.com
}

\begin{abstract}
An experiment was conducted to investigate the effect of different levels of cadmium (Cd) stress on germination, morphology, physiology and yield of rice. There were five treatments, viz. control (no Cd), $0.5 \mathrm{mM}$ $\mathrm{CdCl}_{2}, 1 \mathrm{mM} \mathrm{CdCl}_{2}, 1.5 \mathrm{mM} \mathrm{CdCl}_{2}$ and $2 \mathrm{mM} \mathrm{CdCl}_{2}$, carried out by a randomized complete block design (RCBD) with three replications. Cadmium stress caused a significant reduction of plant height and tillers hill $^{-1}$ in a dosedependent manner. The highest decline of relative water content and SPAD value was found at $1.5 \mathrm{mM}$ (11 and 16\%) and $2 \mathrm{mM}\left(14\right.$ and 19\%) Cd stress compared to the control. The number of effective tillers hill ${ }^{-1}$, filled grains panicle ${ }^{-1}$, 1000 -grain weight, length of panicle, grain yield and straw yield reduced significantly by $44,32,15,24,37$ and $45 \%$, respectively, over the control. Germination and seedling-related parameters were recorded 10 days after germination. The lowest germination percentage (27\%), germination index (27\%) and seedling vigour index (49\%) were observed at the highest level of $\mathrm{Cd}$ stress in comparison to the control. Cadmium stress resulted in maximum abnormal seedlings and markedly reduced length of root and shoot as well as their fresh and dry weight. Root shoot ratio showed differential responses to $\mathrm{Cd}$ stress. Thus, it can be concluded that a higher level of $\mathrm{Cd}$ in soil has a detrimental effect on seed germination, morphology, physiology and yield of rice.
\end{abstract}

Keywords: Metal toxicity, abiotic stress, seed germination, yield components, soil pollution, SPAD value

\section{Introduction}

Stressful environmental conditions continuously challenge plants and lead to physiological and biochemical changes. Among the abiotic stresses, heavy metal stress is the most devastating, which has acquired considerable attention over the last 30 years [1]. Earth's crust contains varying levels of different metals/metalloids, among them, some essential for plant cells, viz. copper $(\mathrm{Cu})$, iron (Fe), manganese ( $\mathrm{Mn})$, nickel (Ni), zinc ( $\mathrm{Zn})$, at supra-optimum concentrations, and some are considered as harmful even at lower concentrations, e.g. mercury $(\mathrm{Hg})$, cadmium $(\mathrm{Cd})$, arsenic (As), chromium $(\mathrm{Cr})$ and lead $(\mathrm{Pb})$ [2]. Heavy metals/metalloids are non-biodegradable in nature and the excess amount may reduce stomatal conductance, photosynthetic and RuBisCo activity, and disrupt the energy production of the plant [3]. Cultivating plants in metal-contaminated soil may cause metabolic dysfunction and reduced germination and growth, and cause chlorosis, root browning and ultimately reduced plant yield [4]. Plants produce excessive reactive oxygen species (ROS) in stress condition and cause damage to their photosynthetic apparatus and functional elements [5].

Among heavy metals, cadmium $(\mathrm{Cd})$ is considered a non-essential element for plants. Due to different anthropogenic processes, rapid industrialization and overpopulation, the amount of $\mathrm{Cd}$ is increasing in the soil, which causes deterioration of soil health and reduces crop growth [6]. 
Plants readily absorb $\mathrm{Cd}$ from soil and easily transfer it to their above-ground parts. Plants growing in Cd-contaminated growth media showed different physiological and biochemical disorders. Germination percentage, root and shoot length are greatly hampered by $\mathrm{Cd}$ stress, due to which the number of abnormal seedlings increases [7, 8]. It also impairs different metabolic processes, which induce water and nutrient unavailability in the plant and ultimately reduce plant growth and yield [9].

Rice is considered the third most important global cereal crop after wheat and maize. It can accumulate $\mathrm{Cd}$ in both root and shoot regions of plants [10]. Several studies have found that rice could accumulate $\mathrm{Cd}$ even at a lower concentration in soil and thus easily enter into the human food chain $[11,12]$. It also alters chloroplast structure, reduces total chlorophyll (chl) content and net photosynthesis rate, which retards the normal functioning of plant and reduces the growth of rice [11]. Delayed germination and interrupted radicle development are also observed in rice under $\mathrm{Cd}$ stress [13]. Cadmium stress reduced biomass and dry weight of rice and also water uptake, which created an osmotic imbalance in the plant [14]. Rice can translocate $\mathrm{Cd}$ in grain, which reduces yield quality and quantity [15]. In addition, tiller number, filled spikelet, spikelet number and 1000-grain weight of rice plant decreases due to the presence of $\mathrm{Cd}$ in soil [16].

The effect of $\mathrm{Cd}$ on the growth and yield parameters of rice should be examined to overcome the negative effect of $\mathrm{Cd}$ on crop growth and to minimize the yield loss. Previous literature demonstrates the harmful effects of $\mathrm{Cd}$ on the rice plant [17]. However, in hydroponic or semi-hydroponic medium, lower doses of Cd could result in severe damages [18], whereas in solid medium, even several times higher doses showed a similar outcome. The reason underlying this fact could be the ability of rice plants to uptake $\mathrm{Cd}$ from liquid or semi-liquid mediums more easily compared to solid medium. In addition, a solid medium like soil can create a barrier in the uptake of $\mathrm{Cd}$ by withholding those in soil particles. However, higher concentration of $\mathrm{Cd}$ was also used to study the effect of $\mathrm{Cd}$ under hydroponic condition [17, 19]. Therefore, the present study was designed to investigate the morpho-physiological and yield responses of rice at different levels of Cd stress.

\section{Materials and Methods}

Experimental materials and treatments

BRRI dhan48 was used in the experiment. Earthen pots (18 inches depth) with $12 \mathrm{~kg}$ soil pot $^{-1}$ were used. The experiment consisted of treatments viz. control (no Cd), $0.5 \mathrm{mM} \mathrm{CdCl}, 1$ $\mathrm{mM} \mathrm{CdCl} 2,1.5 \mathrm{mM} \mathrm{CdCl}_{2}, 2 \mathrm{mM} \mathrm{CdCl}$. Addition of $\mathrm{CdCl}_{2}$ in soil was started at 15 days after transplanting (DAT) and continued up to 60 DAT.

\section{Experimental design}

The experiment was laid out in a randomized complete block design (RCBD) with three replications.

\section{Crop husbandry}

Fertilizers were applied as per the recommendation [20]. One-third of urea and the whole amount of other fertilizers and cowdung were incorporated with soil at final pot preparation before transplanting. The rest of the urea was applied in two equal splits at 30 and 45 DAT. Previously collected seeds were soaked for 48 hours and then washed thoroughly in fresh water and incubated for sprouting. The sprouted seeds were sown in the wet seedbed. Fifteen-day old 
seedlings from the seedbed were transplanted into the respective pots maintaining two seedlings hill $^{-1}$ and one hill pot ${ }^{-1}$.

Germination percentage

Germination percentage was measured by the following formula-

Germination percentage $=\frac{\text { Number of germinated seed }}{\text { Number of seed placed }} \times 100$

Germination index

According to Karim et al. [21] germination index was measured by the following equationGermination index $=\frac{\text { Germination } \% \text { in each treatment }}{\text { Germination } \% \text { in the control }} \times 100$

Abnormal seedlings percentage

The abnormal seedlings were classified according to the formal rules given by ISTA [22].

Shoot and root length of seedling

Shoot and root length was measured from ten seedlings randomlyand averaged.

Seedling vigour index

Seedling vigour index can be calculated as the following equation according to Abdel-Baki and Anderson [23]

Seedling vigour index $=($ Average shoot length + Average root length $) \times$ Germination $\%$

Fresh weight of shoot and root

Ten sample seedlings were randomly selected for estimating the mean fresh weight per seedling (FW seedling $\left.{ }^{-1}\right)$. For this purpose, the shoot and root of seedlings were disconnected and weighed in balance separately.

Dry weight of shoot and root

After weighing the fresh weight, shoot and root of seedlings were kept separately in an electric oven maintaining $80^{\circ} \mathrm{C}$ for $48 \mathrm{~h}$ and it was weighed in balance to measure dry weight and then they were averaged.

\section{Root shoot ratio}

Root shoot ratio was calculated by the following formula-

Root shoot ratio $(\mathrm{FW}$ basis $)=\frac{\text { Root FW }}{\text { Shoot FW }} \times 100$

Root shoot ratio $(\mathrm{DW}$ basis $)=\frac{\text { Root } \mathrm{DW}}{\text { Shoot } \mathrm{DW}} \times 100$

Root shoot ratio (Length basis) $=\frac{\text { Root length }}{\text { Shoot length }} \times 100$

\section{Plant height}

The height of the rice plants was recorded from 30 DAT at 15-day intervals up to harvest; beginning from the ground level up to the tip of the leaf was measured as the height of the plant.

Tiller number hill ${ }^{-1}$

Total tiller number was taken from 30 DAT at 15-day intervals up to harvest. 


\section{HASANUZZAMAN}

\section{Relative water content}

Leaf relative water content (RWC) was measured according to Barrs and Weatherley [24]. Three leaf laminas were weighed (FW) and then immediately floated on distilled water in a Petri dish for $4 \mathrm{~h}$ in the dark. Turgid weight (TW) was obtained after removing excess surface water with paper towels. Dry weight (DW) was measured after drying at $80^{\circ} \mathrm{C}$ for $48 \mathrm{~h}$. Then calculation was done using the following formula:

$$
\text { RWC }(\%)=\frac{F W-D W}{T W-D W} \times 100 \text {. }
$$

SPAD values

Five leaves were randomly selected per pot. The top, middle and base of each leaf were measured with the Soil Plant Analysis Development (SPAD, Minolta Camera Co., Osaka, Japan) meter. Then it was averaged and total chl content was measured by the conversion of SPAD units to totals chl content (Yuan et al. 2016).

Effective and non-effective tillers hill $^{-1}$

The total number of tillers hill-1 was counted from selected samples and were grouped in effective and non-effective tillers hill ${ }^{-1}$.

Number of filled and unfilled grains panicle $e^{-1}$

Grains of 5 randomly selected panicles from each pot were counted, and then the average number of grains for each panicle was determined.

\section{Length of panicle}

Length of panicle was recorded from the basal nodes of the rachis to the apex of each panicle.

\section{0-grain weight}

One thousand cleaned, sun-dried grains were counted from the seed stock obtained from the sample plants and weighed using an electronic balance.

Grain yield pot ${ }^{-1}$ weighed.

The grains were separated by threshing on a per plant basis and then sun-dried and

Straw yield pot ${ }^{-1}$

The straw was separated by threshing and weighed on a per plant basis.

\section{Statistical analysis}

The data obtained for different parameters were statistically analysed following computerbased software Statistix 10.0 and mean separation was done by LSD at 5\% level of significance.

\section{Results}

Seed germination parameters

A sharp decline in germination percentage was observed under different levels of Cd stress. When subjected to $0.5,1,1.5$ and $2 \mathrm{mM} \mathrm{CdCl}_{2}$, plants exhibited $15,14,17$ and $27 \%$ reduction in the germination percentage, respectively, in comparison to the control (Fig.1A). At different levels of $\mathrm{Cd}$ exposure, primary roots become decayed, stunted and split at the tip. Short, thick, constricted and spiral hypocotyls were also observed. The epicotyl became discolored, decayed and bent over during $\mathrm{Cd}$ exposure and the absence of terminal buds was also observed. However, abnormal 
seedlings remarkably increased with the increase of $\mathrm{Cd}$ concentration where the maximum abnormal seedlings (82\%) were recorded at $2 \mathrm{mM} \mathrm{Cd}$ stress and, at other levels of Cd stress, it was higher than the control but similar within those treatments (Fig. 1B). Germination index was decreased with the increase in the concentration of the $\mathrm{CdCl}_{2}$. Moreover, germination index was reduced by $14-27 \%$ due to the application of 0.5 to $2 \mathrm{mM}$ of $\mathrm{CdCl}_{2}$, compared to the control (Fig. 1C). In Cd-stressed plants, seedling vigour index sharply reduced in a dose-dependent manner, in comparison to the control. Seedling vigour index was decreased by 24, 28, 36 and 49\% upon exposure to $0.5,1,1.5$ and $2 \mathrm{mM} \mathrm{Cd}$ stress, respectively, compared to the control (Fig. 1D).

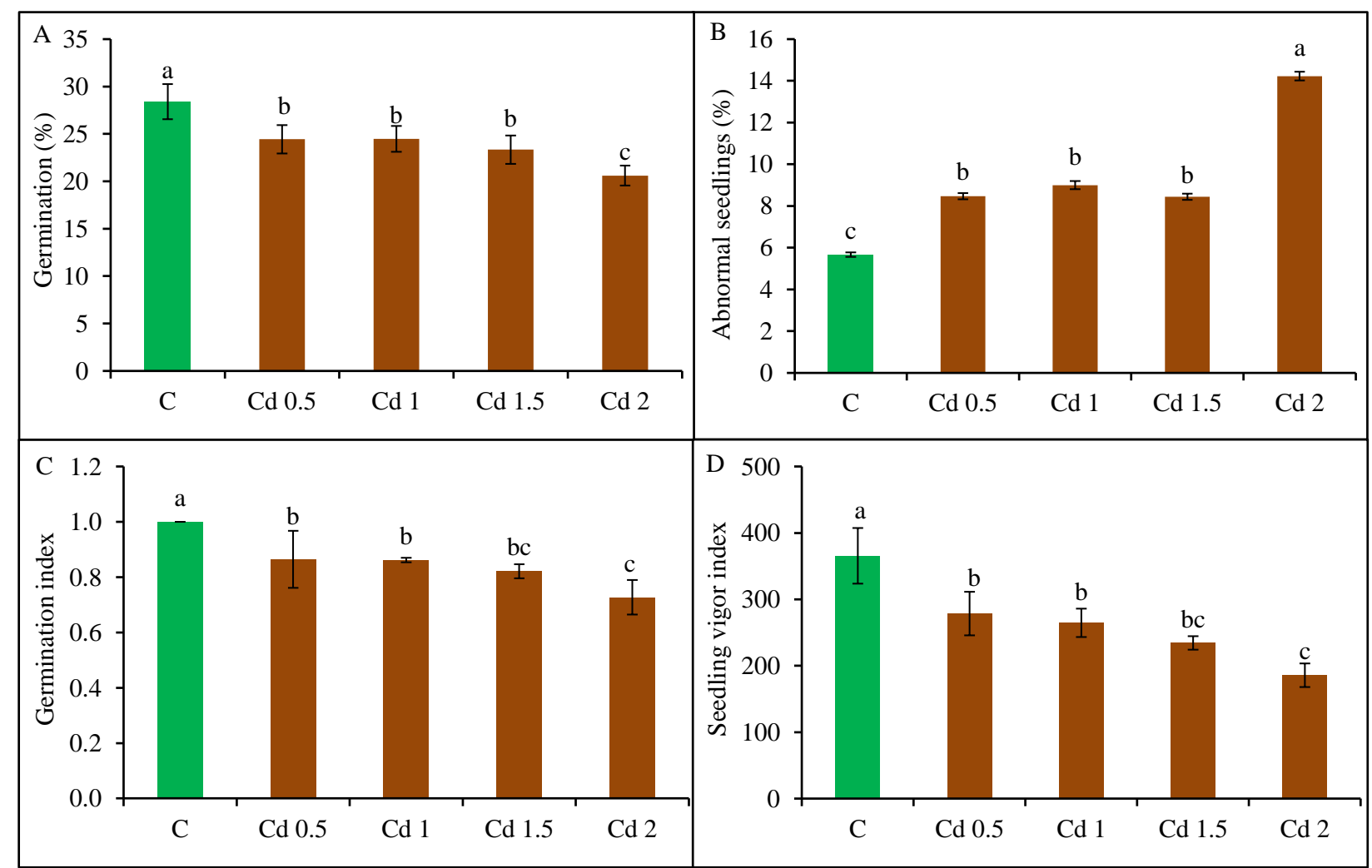

Fig. 1: Effect of different Cd levels on germination percentage (A), abnormal seedlings percentage (B), germination index $(C)$ and seedling vigor index (D) of rice $(O$. sativa) seedlings. Here, $\mathrm{C}=$ control, $\mathrm{Cd}$ $0.5=0.5 \mathrm{mM} \mathrm{CdCl}_{2}, \mathrm{Cd} 1=1 \mathrm{mM} \mathrm{CdCl}_{2}, \mathrm{Cd} 1.5=1.5 \mathrm{mM} \mathrm{CdCl}_{2}, \mathrm{Cd} 2=2 \mathrm{mM} \mathrm{CdCl}_{2}$. Mean $( \pm \mathrm{SD})$ was calculated from three replicates for each treatment. Values with different letters are significantly different at $P \leq 0.05$ applying Fisher's LSD test

\section{Seedling growth and biomass production}

Due to imposition of $0.5,1,1.5$ and $2 \mathrm{mM} \mathrm{Cd}$ stress, shoot length was reduced by 18,22 , 24 and 34\%, respectively in comparison to the control (Fig. 2A). In Cd-stressed plants, reduction of the root length was observed with the increase in the Cd concentration, in comparison to nonstressed plants. At $2 \mathrm{mM} \mathrm{Cd}$ stress, root length was reduced by $25 \%$ compared to the control (Fig. 2B). All the levels of Cd supplementation decreased the shoot FW, compared to the control. Different levels of Cd treatments caused $17-29 \%$ reduction in the FW of shoot (Fig. 2C). Under different levels of Cd stress, DW of seedlings shoot was negatively affected, over control. Moreover, shoot DW of seedlings was decreased from $9 \%$ to $30 \%$ when subjected to 0.5 to $2 \mathrm{mM}$ Cd stress, in comparison to non-stressed plant (Fig. 2D). Plants exhibited noticeable reduction in root $\mathrm{FW}$ by $18,52,68$ and $82 \%$ when exposed to $0.5,1,1.5$ and $2 \mathrm{mM} \mathrm{CdCl}_{2}$, respectively, in 


\section{HASANUZZAMAN}

comparison to the control (Fig. 2E). Upon exposure to $0.5,1,1.5$ and $2 \mathrm{mM} \mathrm{CdCl}_{2}$ root DW of seedlings was decreased by 13, 22, 28 and 36\% compared to the control (Fig. 2F).

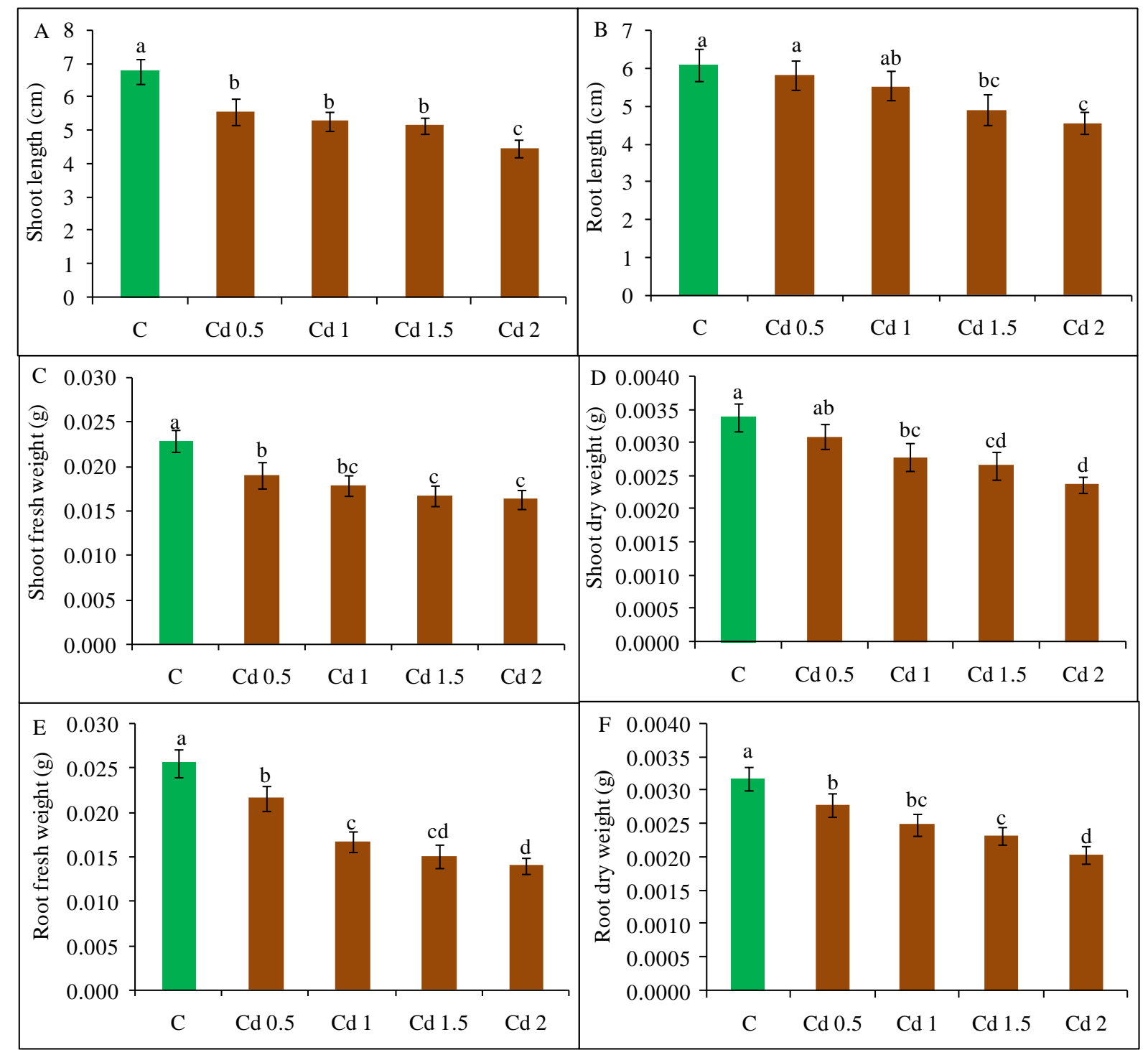

Fig. 2: Effect of different Cd levels on shoot length (A), root length (B), shoot FW (C), shoot DW (D), root FW

(E) and root DW (F) of rice (O. sativa) seedlings. Here, $\mathrm{C}=$ control, $\mathrm{Cd} 0.5=0.5 \mathrm{mM} \mathrm{CdCl}_{2}, \mathrm{Cd} 1=1 \mathrm{mM}$ $\mathrm{CdCl}_{2}, \mathrm{Cd} 1.5=1.5 \mathrm{mM} \mathrm{CdCl}_{2}, \mathrm{Cd} 2=2 \mathrm{mM} \mathrm{CdCl}_{2}$. Mean $( \pm \mathrm{SD})$ was calculated from three replicates for each treatment. Values with different letters are significantly different at $P \leq 0.05$ applying Fisher's LSD test

Application of $0.5 \mathrm{mM} \mathrm{CdCl}_{2}$ increased the root shoot ratio, whereas in higher doses of $\mathrm{Cd}$ stress root-shoot ratio was decreased over control (Fig. 3A). When subjected to 0.5 to $2 \mathrm{mM} \mathrm{Cd}$ stress, root-shoot ratio (DW basis) of the seedlings was decreased from $2 \%$ to $10 \%$, in comparison to the control (Fig. 3B). Root-shoot ratio (length basis) of the seedlings was also negatively affected by the different levels of Cd treatments (Fig. 3C).

\section{Growth parameters}

Plant height

Upon exposure to $0.5,1,1.5$ and $2 \mathrm{mM} \mathrm{CdCl}_{2}$-induced stress, plant height decreased in a dose-dependent manner at all growth stages but the reduction was not remarkable. At 30, 45, 60, 
75 and 90 DAT and at harvest the reduction of the plant height ranged from 5 to 7, 4 to 11,5 to 13,7 to 13,7 to 14 and 5 to $13 \%$, respectively, when subjected to different levels of $\mathrm{Cd}$ stress, in comparison to the control (Fig. 4A-F).

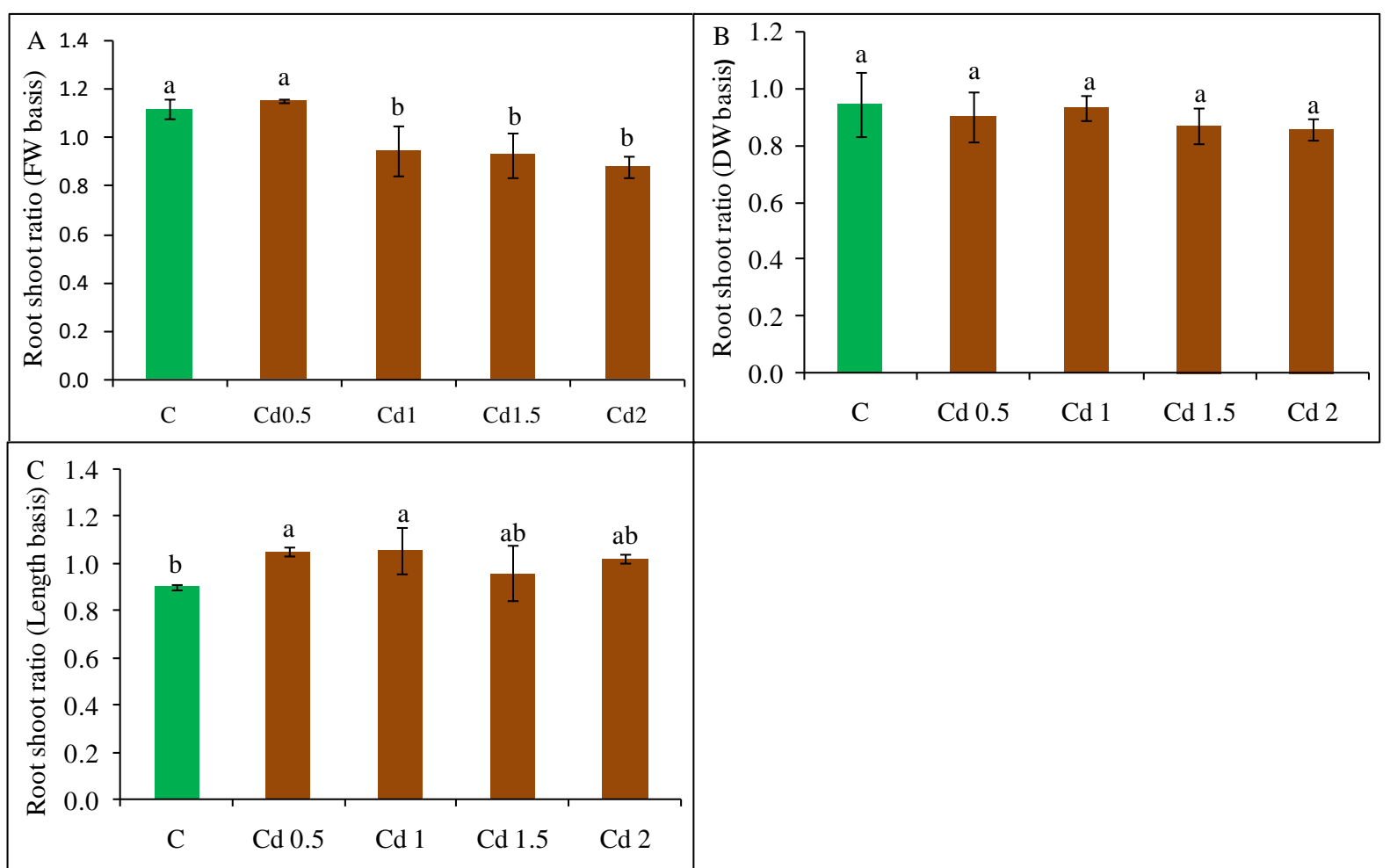

Fig. 3: Effect of different Cd levels on root shoot ratio (FW basis) (A), root shoot ratio (DW basis) (B) and root shoot ratio (length basis) $(\mathbf{C})$ of rice $\left(\boldsymbol{O}\right.$. sativa) seedlings. Here, $\mathrm{C}=$ control, $\mathrm{Cd} 0.5=0.5 \mathrm{mM} \mathrm{CdCl}_{2}, \mathrm{Cd}_{1}$ $=1 \mathrm{mM} \mathrm{CdCl}_{2}, \mathrm{Cd} 1.5=1.5 \mathrm{mM} \mathrm{CdCl}_{2}, \mathrm{Cd} 2=2 \mathrm{mM} \mathrm{CdCl}_{2}$. Mean $( \pm \mathrm{SD})$ was calculated from three replicates for each treatment. Values with different letters are significantly different at $P \leq 0.05$ applying Fisher's LSD test

Number of tillers hill ${ }^{-1}$

In response to $\mathrm{Cd}$-induced stress, the number of tillers hill ${ }^{-1}$ noticeably decreased with the increase in the concentration of the $\mathrm{Cd}$. When exposed to 0.5 to $2 \mathrm{mM} \mathrm{Cd}$ stress plant exhibited 11 to 28,15 to 35,13 to 25,11 to 27,12 to 28 and 10 to $26 \%$ reduction in the number of tillers hill ${ }^{-1}$ at 30, 45, 60, 75, 90 DAT and at harvest, respectively, in comparison to the control (Fig. 5A-F).

\section{Physiological parameters}

Relative water content and SPAD value

In Cd-stressed plants, the RWC decreased with the increase in the concentration of the $\mathrm{Cd}$. The leaf RWC reduced by 7, 9, 11 and $16 \%$ at $0.5,1.0,1.5$ and $2.0 \mathrm{mM}$ of Cd stress, respectively, in comparison to the control (Fig. 6A). Cadmium exposure reduced the SPAD value by $10 \%$ and $14 \%$ at higher doses (1.5 and $2 \mathrm{mM}$, respectively) in comparison to the control; however, a slight reduction was also recorded at lower doses (Fig. 6B).

\section{Yield contributing characters}

The number of effective tiller hill ${ }^{-1}$ sharply decreased in Cd-stressed plants in a dosedependent manner, in comparison to control plants. Upon exposure to $0.5,1,1.5$ and $2 \mathrm{mM} \mathrm{Cd}$ stress, plants exhibited 16, 29, 39 and 44\% reduction in the number of effective tiller hill ${ }^{-1}$, 
respectively, in comparison to the control (Fig. 7A). The imposition of $\mathrm{Cd}$ stress remarkably increased the number of non-effective tillers hill ${ }^{-1}$, with the increase of the $\mathrm{Cd}$ concentration. The highest number of non-effective tillers hill ${ }^{-1}(90 \%)$ was observed at the maximum level of Cd stress. A similar increasing trend of the number of non-effective tillers hill ${ }^{-1}$ was observed at 0.5 , 1 and $1.5 \mathrm{mM} \mathrm{Cd}$ stress, which were by 26,34 and $49 \%$, respectively, in comparison to the control (Fig. 7B). When exposed to $0.5,1,1.5$ and $2 \mathrm{mM} \mathrm{Cd}$ stress, the plants exhibited a reduction in the number of filled grain panicle ${ }^{-1}$ by $6,13,16$ and $32 \%$, respectively, in comparison to the control (Fig. 7C). A dose-dependent increase was observed in the number of unfilled grain panicle ${ }^{-1}$. Application of 0.5 to $2 \mathrm{mM} \mathrm{Cd}$ increased the number of unfilled grain panicle ${ }^{-1}$ ranged from 13 to $30 \%$, in comparison to the control (Fig. 7D). In response to different levels of Cd stress (0.5-2 $\mathrm{mM}$ ) length of panicle decreased, in a dose-dependent manner. When subjected to $0.5,1.0,1.5$ and $2 \mathrm{mM} \mathrm{Cd}$ stress panicle length decreased by 9, 13, 19 and 24\%, respectively, in comparison to control (Fig. 7E). All the Cd treatments decreased the 1000-grain weight, in a dose-dependent manner. The reduction of the 1000 -grain weight ranged from $3 \%$ to $15 \%$ upon exposure to $0.5,1$, 1.5 and $2 \mathrm{mM} \mathrm{CdCl}_{2}$, in comparison to the control $(7 \mathrm{~F})$.

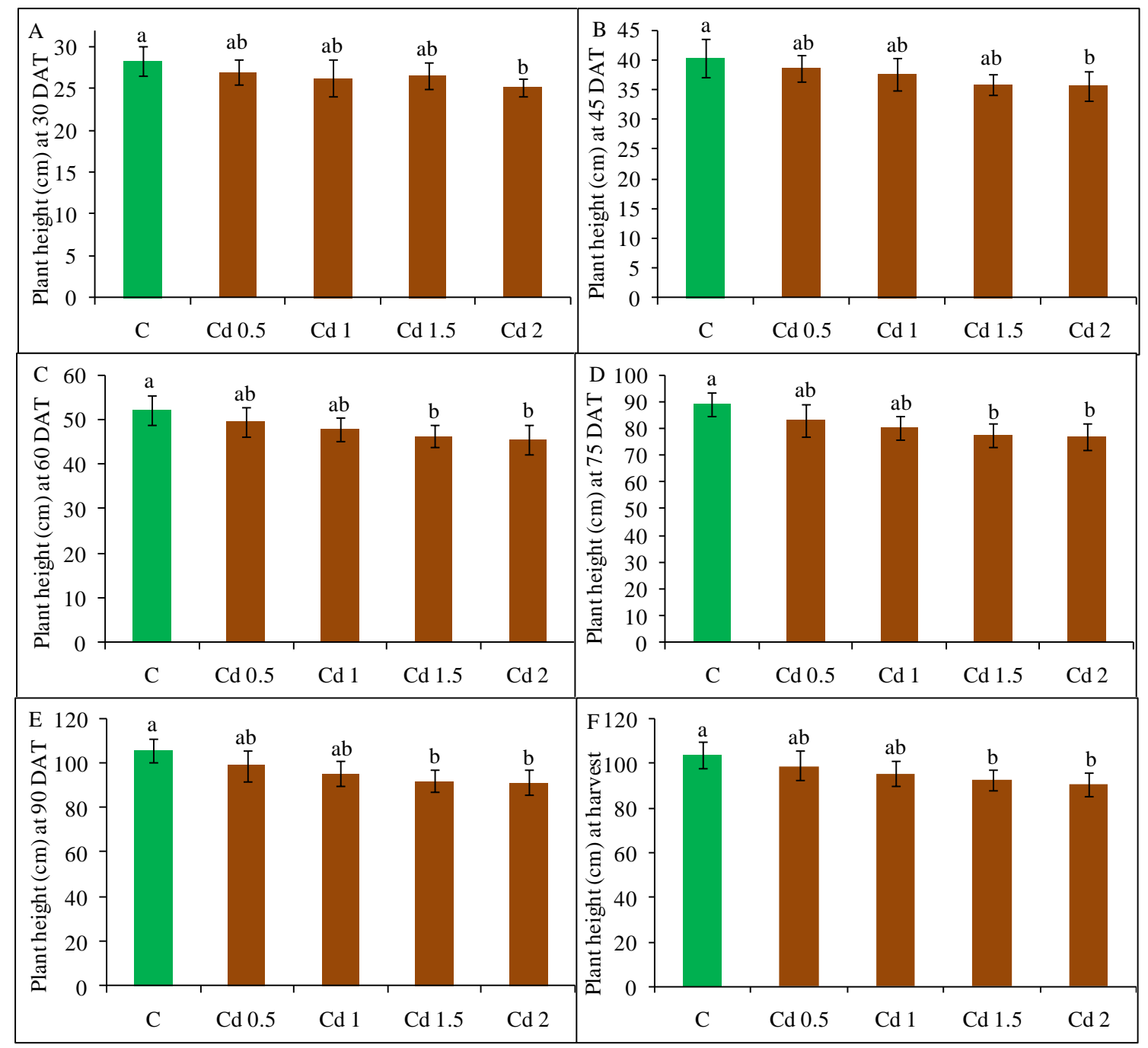

Fig. 4: Effect of different Cd levels on plant height of rice (O. sativa) at 30 (A), 45 (B), 60 (C), 75 (D), 90 (E) DAT and at harvest (F). Here, $\mathrm{C}=$ control, $\mathrm{Cd} 0.5=0.5 \mathrm{mM} \mathrm{CdCl}_{2}, \mathrm{Cd} 1=1 \mathrm{mM} \mathrm{CdCl}_{2}, \mathrm{Cd} 1.5=1.5 \mathrm{mM} \mathrm{CdCl}_{2}$, $\mathrm{Cd} 2=2 \mathrm{mM} \mathrm{CdCl}_{2}$. Mean $( \pm \mathrm{SD})$ was calculated from three replicates for each treatment. Values with different letters are significantly different at $P \leq 0.05$ applying Fisher's LSD test. 


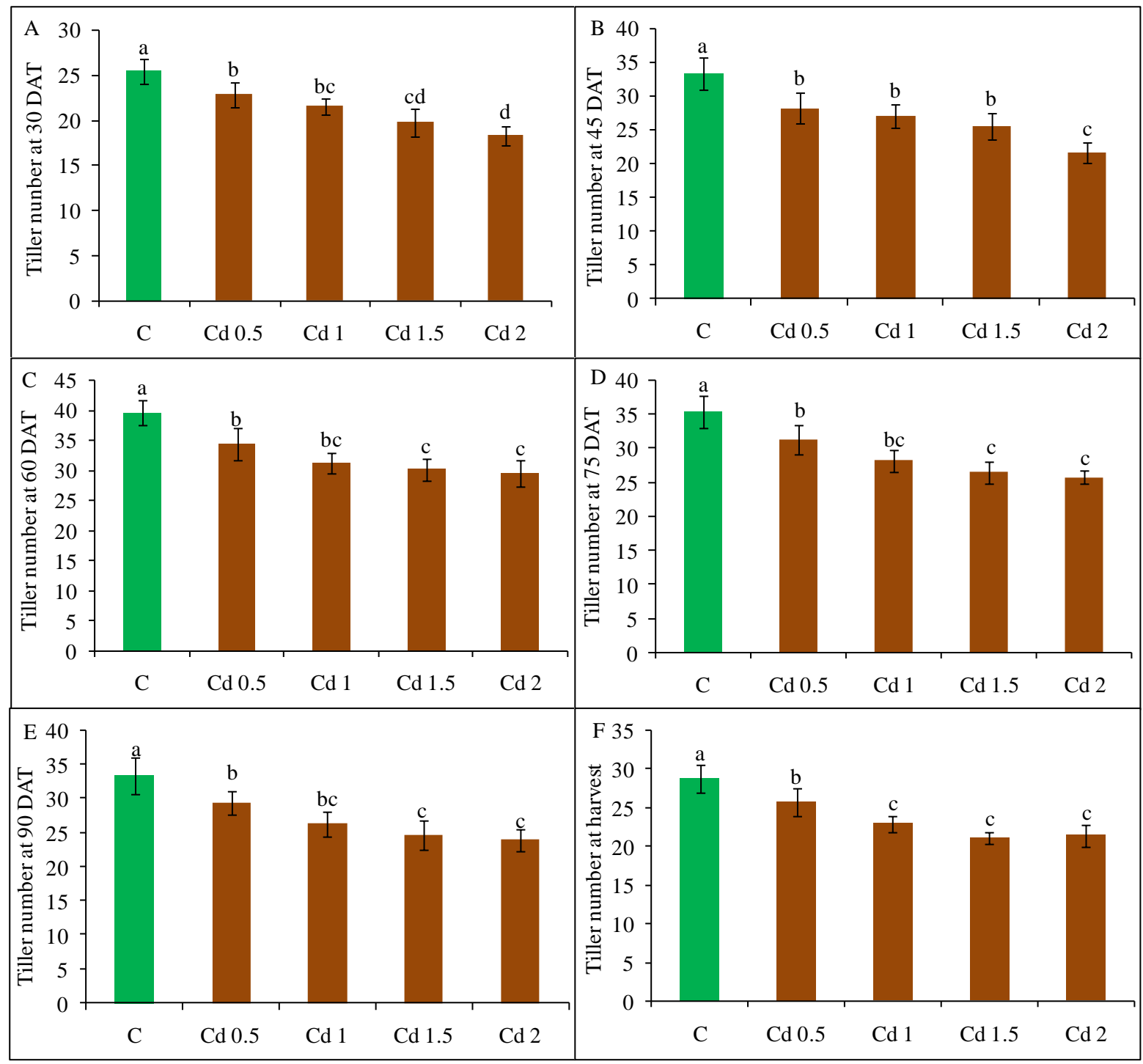

Fig. 5: Effect of different Cd levels on tillers hill ${ }^{-1}$ of rice (O. sativa) at 30 (A), 45 (B), 60 (C), 75 (D), 90 (E) DAT and at harvest (F). Here, $\mathrm{C}=$ control, $\mathrm{Cd} 0.5=0.5 \mathrm{mM} \mathrm{CdCl}_{2}, \mathrm{Cd} 1=1 \mathrm{mM} \mathrm{CdCl}_{2}, \mathrm{Cd} 1.5=1.5 \mathrm{mM} \mathrm{CdCl}_{2}$, $\mathrm{Cd} 2=2 \mathrm{mM} \mathrm{CdCl}_{2}$. Mean $( \pm \mathrm{SD})$ was calculated from three replicates for each treatment. Values with different letters are significantly different at $P \leq 0.05$ applying Fisher's LSD test.

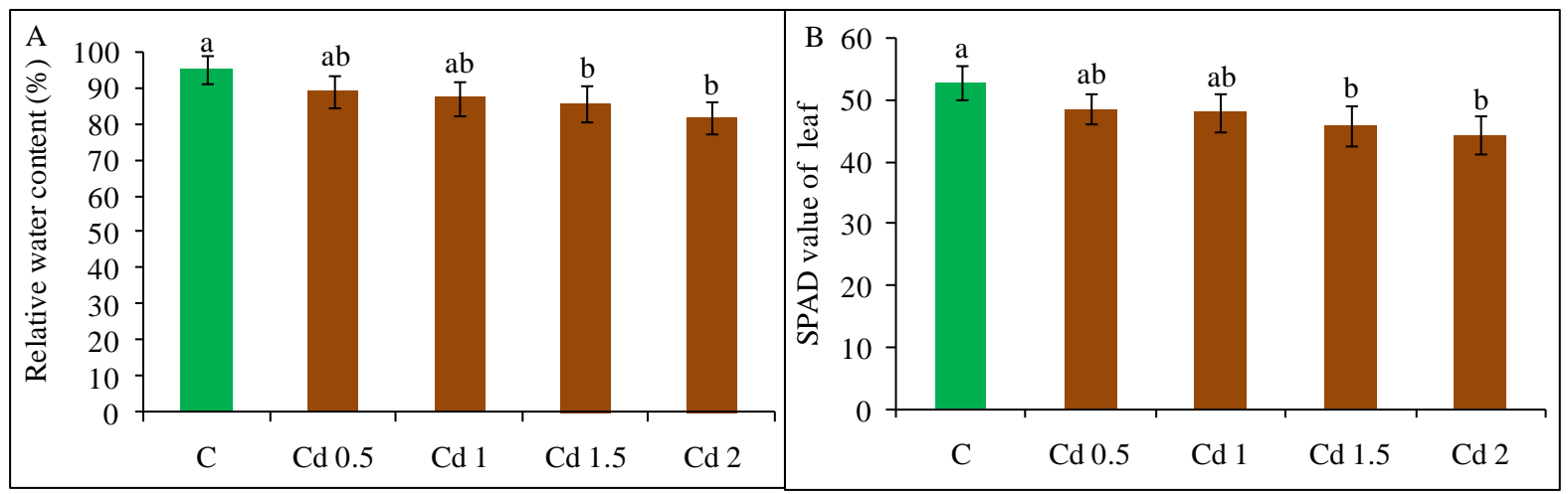

Fig. 6: Effect of different Cd levels on RWC (A) and SPAD value (B) of rice (O. sativa). Here, $\mathrm{C}=$ control, $\mathrm{Cd} 0.5$ $=0.5 \mathrm{mM} \mathrm{CdCl}_{2}, \mathrm{Cd} 1=1 \mathrm{mM} \mathrm{CdCl}_{2}, \mathrm{Cd} 1.5=1.5 \mathrm{mM} \mathrm{CdCl}_{2}, \mathrm{Cd} 2=2 \mathrm{mM} \mathrm{CdCl}_{2}$. Mean ( \pm SD) was calculated from three replicates for each treatment. Values with different letters are significantly different at $P$ $\leq 0.05$ applying Fisher's LSD test. 


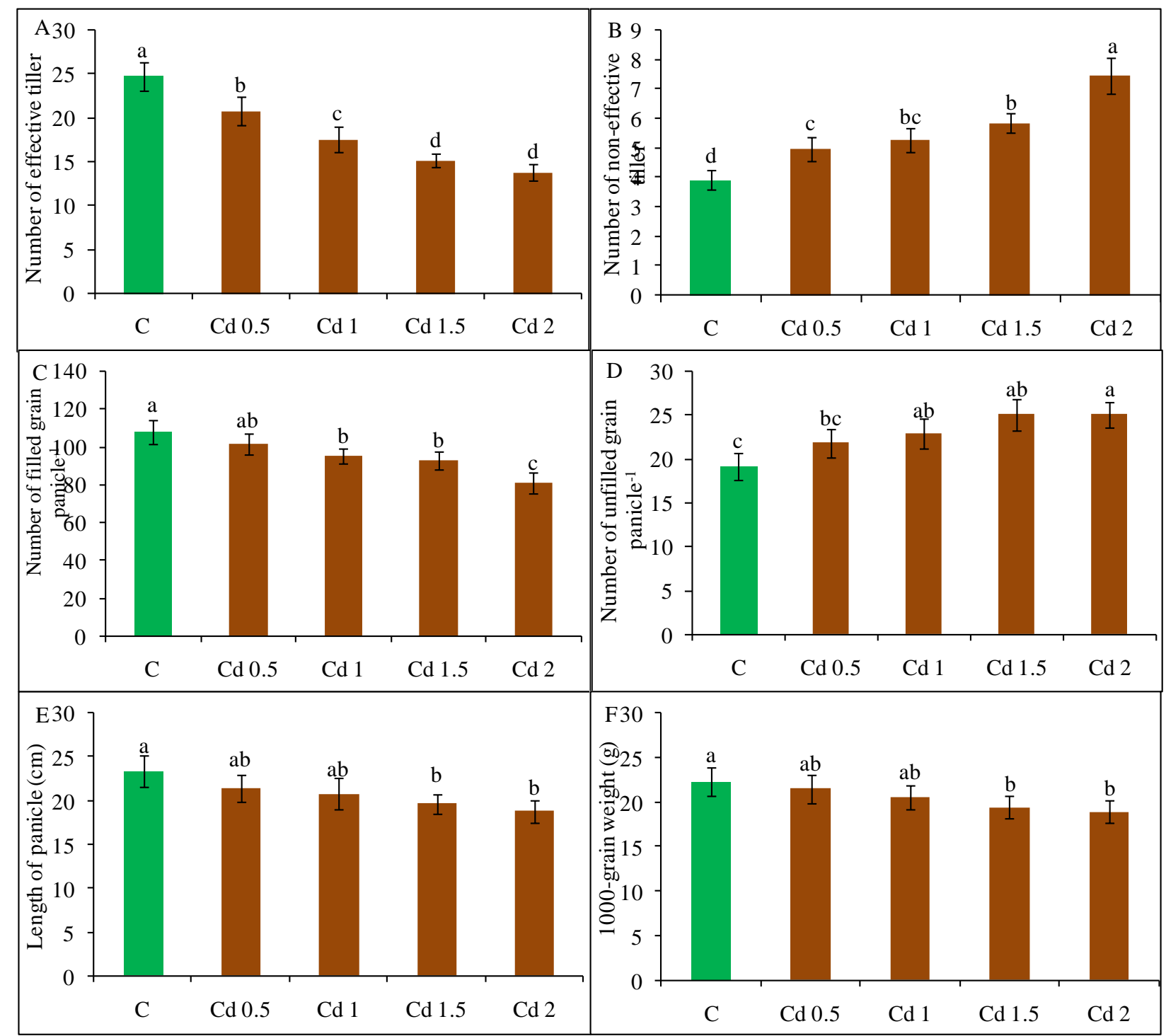

Fig. 7: Effect of different Cd levels on number of effective tillers hill ${ }^{-1}(A)$, non-effective tillers hill $^{-1}(B)$, filled grains panicle $^{-1}(C)$, non-filled grains panicle ${ }^{-1}(D)$, length of panicle $(E)$ and 1000-grain weight $(F)$ of rice (O. sativa). Here, $\mathrm{C}=$ control, $\mathrm{Cd} 0.5=0.5 \mathrm{mM} \mathrm{CdCl}_{2}, \mathrm{Cd} 1=1 \mathrm{mM} \mathrm{CdCl}_{2}, \mathrm{Cd} 1.5=1.5 \mathrm{mM} \mathrm{CdCl}_{2}, \mathrm{Cd}$ $2=2 \mathrm{mM} \mathrm{CdCl}_{2}$. Mean $( \pm \mathrm{SD})$ was calculated from three replicates for each treatment. Values with different letters are significantly different at $P \leq 0.05$ applying Fisher's LSD test

\section{Yield}

Sharp reduction in grain yield was observed in response to different levels of Cd stress. The maximum reduction of the grain yield (37\%) was observed at the highest level of Cd stress. Similarly, at $0.5,1$ and $1.5 \mathrm{mM} \mathrm{Cd}$ stress, the reduction was 12,23 and $29 \%$, respectively, in comparison to the control plants (Fig. 8A). In Cd-stressed plants, straw yield also reduced noticeably by $13,25,36$ and $45 \%$ at $0.5,1,1.5$ and $2 \mathrm{mM} \mathrm{Cd}$ stress, respectively, in comparison to normal plants (Fig. 8B). 


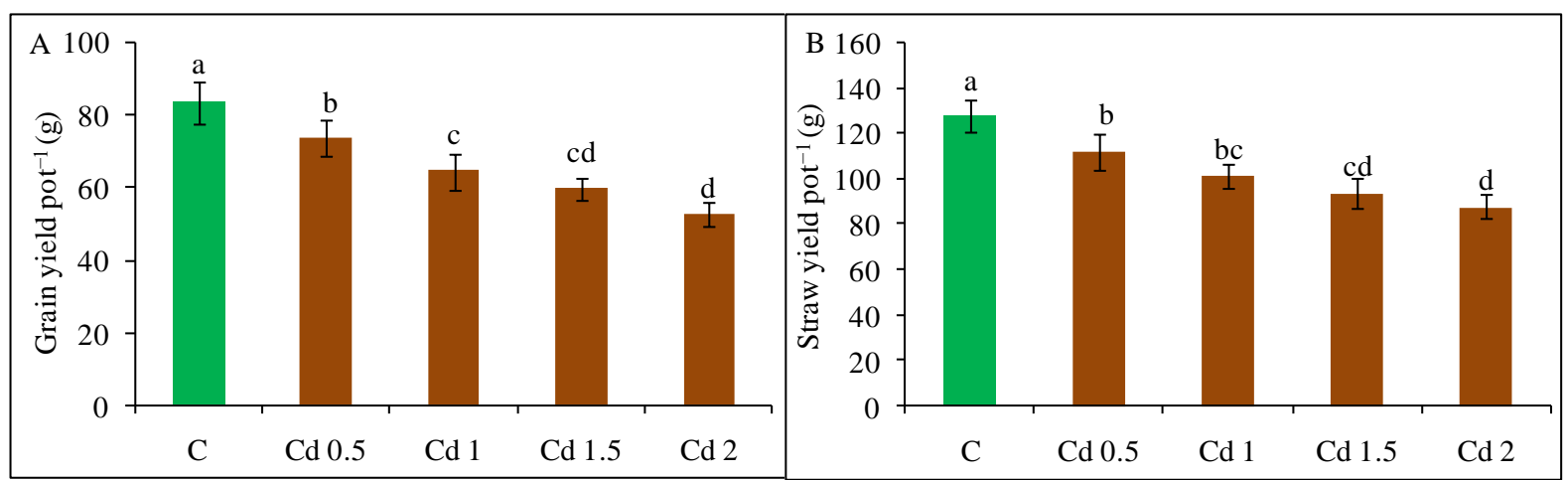

Fig. 8: Effect of different $\mathrm{Cd}$ levels on grain yield $(\mathrm{A})$ and straw yield $(\mathrm{B})$ of rice $(\boldsymbol{O}$. sativa). Here, $\mathrm{C}=$ control, $\mathrm{Cd} 0.5=0.5 \mathrm{mM} \mathrm{CdCl}_{2}, \mathrm{Cd} 1=1 \mathrm{mM} \mathrm{CdCl}_{2}, \mathrm{Cd} 1.5=1.5 \mathrm{mM} \mathrm{CdCl}_{2}, \mathrm{Cd} 2=2 \mathrm{mM} \mathrm{CdCl}_{2}$. Mean ( $\pm \mathrm{SD}$ ) was calculated from three replicates for each treatment. Values with different letters are significantly different at $P$ $\leq 0.05$ applying Fisher's LSD test

\section{Discussion}

Seed germination plays a basic role in the plant life cycle and is crucial for the establishment of seedlings. Heavy metal stress tends to hamper this phenomenon of seeds irrespective of the stressor type. Our study also revealed lower percentages of germination in all the levels of $\mathrm{Cd}$ stress, but this reduction was not dependent on the doses. The result reveals that beyond the threshold level of $\mathrm{Cd}$, seeds face difficulties in radical and plumule initiation irrespective of the concentration of $\mathrm{Cd}$ they were exposed to. This rationale also implies in case of the length, FW and DW of both the shoot and root of $O$. sativa seedlings and the result is evident from our findings as well as several other studies conducted with different crop species [18, 26, 27]. Another two important parameters of germination are germination index and seedling vigour index, which also showed a remarkable decrease upon exposure to Cd stress and the lowest value was recorded in the highest dose of $\mathrm{Cd}$. Stress-induced loss of cell turgidity has been documented in a number of studies and it leads to decreased seedling vigour index. Experiments with various crops demonstrating the effect of $\mathrm{Cd}$ stress on seed germination also revealed similar findings [28, 29, 30]. One important parameter measured in this experiment was the root-shoot ratio of seedlings as it was recorded to be affected only when calculated as FW basis, not when as DW basis. Such differences prevail as during the FW-based measurement the moisture content of plant cells is included, which is a major part of a living plant, but DW-based calculation exclude that major amounts and thus the differences remain minor. Both Jung et al. [26] and Imran et al. [31] documented such deviations of fresh and dry weight-based measurements of rice under Cd stress conditions.

Cadmium stress-induced degradation of plant growth has been documented in a number of studies conducted with different plant species, including rice [15, 26, 32]. Our study indicates that the plant height of the Cd-exposed plants is mostly affected at higher doses (1.5 and $2 \mathrm{mM})$ of $\mathrm{Cd}$, whereas doses lower than that could not affect plant height of rice. On the contrary, even the lowest concentration of Cd notably reduced the tiller number hill ${ }^{-1}$ of this rice cultivar, which is considered to be an important attribute of rice growth directly related to yield. Cadmium toxicity imposes adverse effects on photosynthesis, which leads to a reduction of root growth, vital metabolic processes and ultimately overall plant growth [26, 33].

Leaf relative water content is an important parameter of plant physiology as it helps to denote the ability of plants to cope with stress conditions. The more the plant loses water, the less it 


\section{HASANUZZAMAN}

becomes able to tolerate unfavourable conditions and ultimately growth decreases. In our experiment, Cd doses of 1.5 and $2 \mathrm{mM}$ resulted in remarkably lower contents of RWC compared to the control plants, although 0.5 and $1 \mathrm{mM} \mathrm{Cd}$ showed a negligible decline of leaf RWC as these lower amounts of Cd could not damage the cellular components significantly. Such dosedependent reduction of leaf RWC is supported by other studies with various rice cultivars [18, 26]. The same reason lies behind the fact that only at higher levels of $\mathrm{CdCl}_{2}(1.5$ and $2 \mathrm{mM})$ exposure, SPAD value of rice leaves were decreased. Cadmium stress-induced features such as decline in photosynthetic pigment content has also been reported in previous studies with different varieties of rice $[18,34,35]$.

Among the yield parameters, the number of effective tillers plant ${ }^{-1}$ exhibited a dosedependent reduction, as when plants are exposed to toxic metals like $\mathrm{Cd}$, their growth and physiology is negatively affected and their nutrient uptake is reduced, which ultimately leads to yield loss. The number of filled grains panicle ${ }^{-1}$ was also lessened with the increment of applied $\mathrm{Cd}$ doses. A vice-versa occurred in the number of effective tillers plant ${ }^{-1}$ and non-filled grains panicle $^{-1}$; those increased with the increasing concentration of $\mathrm{Cd}$ and were much higher than the control plants. The increment in the number of filled grains panicle ${ }^{-1}$ is correlated with the length of the panicle and hence a similar elevation of this data was observed in this experiment followed by 1000 -grain weight. However, both grain yield and straw yield also showed a notable decline under Cd stress which happened in a dose-dependent manner of the doses. Such reductions of yield attributes by $\mathrm{Cd}$ exposure have been reported in several studies with different plant species as well as rice $[16,34]$.

\section{Conclusion}

Heavy metals such as Cadmium are always considered to be toxic for plant growth, physiology and development, including germination, and there are numerous studies that support the findings of our experiment. However, the lower doses like 0.5 or $1 \mathrm{mM}$ sometimes showed similar data with control plants but there were changes in a negligible amount. Parameters contributing to germination and seedling establishment were observed to be greatly hampered by the minimum concentration of $\mathrm{Cd}$ used, whereas morpho-physiological parameters were mostly affected by higher levels of $\mathrm{Cd}$ stress. However, it is evident from this experiment that $\mathrm{Cd}$ exposure can remarkably reduce the tiller numbers as well as the number of effective tillers, which eventually resulted in a significant reduction in both grain and straw yield of $O$. sativa, and these effects are correlated with the dosage of $\mathrm{Cd}$. Further investigations should be conducted using different phytoprotectants, hormones or management practices to understand if plants can possess any response mechanism to such toxic metal stress.

\section{REFERENCES}

1. De Caroli, M., Furini, A., Dalcorso, G., Rojas, M., Sansebastiano, G.P.D., 2020, Endomembrane reorganization induced by heavy metals, Plants, 9: 482.

2. Anjum, N.A., Singh, H.P., Khan, M.I.R., Masood, A., Per, T.S., Negi, A., 2015, Too much is bad - an appraisal of phytotoxicity of elevated plant-beneficial heavy metal ions, Environmental Science and Pollution Research, 22: 336-3382. 
3. Wang, S.L., Xu, X.R., Sun, Y.X., 2013, Heavy metal pollution in coastal areas of South China: a review, Marine Pollution Bulletin, 76: 7-15.

4. Amari, T., Ghnaya, T., Abdelly, C., 2017, Nickel, cadmium and lead phytotoxicity and potential of halophytic plants in heavy metal extraction, South African Journal of Botany, 111: 99-110.

5. Hasanuzzaman, M., Bhuyan, M.H.M.B., Parvin, K., Bhuiyan, T.F., Anee, T.I., Nahar, K., Hossen, M.S., Zulfiqar, F., Alam, M.M., Fujita, M., 2020, Regulation of ROS metabolism in plants under environmental stress: a review of recent experimental evidence, International Journal of Molecular Sciences, 21: 8695.

6. Huang, R., Dong, M., Mao, P., Zhuang, P., Paz-Ferreiro, J., Li, Y., Li, Y., Hu, X., Netherway, P., Li, Z., 2020, Evaluation of phytoremediation potential of five Cd (hyper) accumulators in two $\mathrm{Cd}$ contaminated soils, Science of the Total Environment, 721: 137581.

7. Rizwan, M., Meunier, J.D., Davidian, J.C., Pokrovsky, O.S., Bovet, S., Keller, C., 2016, Silicon alleviates Cd stress of wheat seedlings (Triticum turgidum L. cv. Claudio) grown in hydroponics, Environmental Science and Pollution Research, 23: 1414-1427.

8. Huang, Z.Q., Ye, S.C., Hu, L.Y., Hu, K.D., Yan, H., Li, W.J., Zhang, H., 2016, Hydrogen sulfide promotes wheat grain germination under cadmium stress, Biological Sciences, 86: 887-895.

9. Ehsan, S., Ali, S., Noureen, S., Mahmood, K., Farid, M., Ishaque, W., Shakoor, M.B., Rizwan, M., 2014, Citric acid assisted phytoremediation of cadmium by Brassica napus L., Ecotoxicology and Environmental Safety, 106: $164-172$.

10. Rizwan, M., Ali, S., Akbar, M.Z., Shakoor, M.B., Mahmood, A., Ishaque, W., Hussain, A., 2017, Foliar application of aspartic acid lowers cadmium uptake and Cd-induced oxidative stress in rice under Cd stress, Environmental Science and Pollution Research, 24: 21938-21947.

11. Rehman, M.Z., Rizwan, M., Ghafoor, A., Naeem, A., Ali, S., Sabir, M., Qayyum, M.F., 2015, Effect of inorganic amendments for in situ stabilization of cadmium in contaminated soils and its phyto-availability to wheat and rice under rotation, Environmental Science and Pollution Research, 22: 16897-16906.

12. Xie, P.P., Deng, J.W., Zhang, H.M., Ma, Y.H., Cao, D.J., Ma, R.X., Liu, R.J., Liu, C., Liang, Y.G., 2015, Effects of cadmium on bioaccumulation and biochemical stress response in rice (Oryza sativa L.), Ecotoxicology and Environmental Safety, 122: 392-398.

13. Sun, Y.L., Liu, H.M., Xu, Q.G., 2017, Effects of cadmium stress on rice seed germination characteristics, Chinese Journal of Rice Science, 31 (4): 425-431.

14. Cai, Y., Zhang, S., Cai, K., Huang, F., Pan, B., Wang, W., 2020, Cd accumulation, biomass and yield of rice are varied with silicon application at different growth phases under high concentration cadmium-contaminated soil, Chemosphere, 242: 125-128.

15. Song, W.E., Chen, S.B., Liu, J.F., 2015, Variation of Cd concentration in various rice cultivars and derivation of cadmium toxicity thresholds for paddy soil by species-sensitivity distribution, Journal of Integrated Agriculture, 4 (9): 1845-1854.

16. Lin, H., Fang, C., Li, Y., Lin, W., He, J., Lin, R., 2016. Effect of silicon on grain yield of rice under cadmiumstress, Acta Physiologiae Plantarum, 38: 186.

17. Bhuyan, M. H. M., Parvin, K., Mohsin, S. M., Mahmud, J. A., Hasanuzzaman, M., Fujita, M., 2020, Modulation of cadmium tolerance in rice: Insight into vanillic acid-induced upregulation of antioxidant defense and glyoxalase systems, Plants, 9 (2): 188.

18. Rahman, A., Mostofa, M. G., Nahar, K., Hasanuzzaman, M., Fujita, M., 2016, Exogenous calcium alleviates cadmium-induced oxidative stress in rice (Oryza sativa L.) seedlings by regulating the antioxidant defense and glyoxalase systems, Brazilian Journal of Botany, 39 (2): 393-407.

19. Paul, S., Roychoudhury, A., 2018, Transcriptome profiling of abiotic stress-responsive genes during cadmium chloride-mediated stress in two indica rice varieties, Journal of Plant Growth Regulation, 37 (2): 657-667.

20. BARC, 2018, Fertilizer Recommendation Guide, Bangladesh Agricultural Research Council, Farmgate, Dhaka, Bangladesh.

21. Karim, M.A., Utsunomiya, N., Shigenaga, S., 1992, Effect of sodium chloride on germination and growth of hexaploid triticale at early seedling stage, Japanese Journal of Crop Sciences, 61: 279-284.

22. ISTA, 1999, International Rules for Seed testing, Seed Science Technology, 2: 25-30.

23. Abdel-Baki, A.A., Anderson, J.D., 1973, Viability and leaching of sugars from germinating barley, Crop Science, 10: 31-34. 
24. Barrs, H.D., Weatherley, P.E., 1962, A reexamination of the relative turgidity technique for estimating water deficits in leaves, Australian Journal of Biological Science, 15: 413-428.

25. Yuan, Z., Cao, Q., Zhang, K., Ata-Ul-Karim, S.T., Tian, Y., Zhu, Y., Cao, W., Liu, X., 2016, Optimal leaf positions for SPAD meter measurement in rice, Frontiers in Plant Science, 7: 719.

26. Jung, H.I., Lee, B.R., Chae, M.J., Kong, M.S., Lee, C.H., Kang, S.S., Kim, Y.H., 2017, Sulfur alleviates cadmium toxicity in rice (Oryza sativa L.) seedlings by altering antioxidant levels, Journal of Crop Science and Biotechnology, 20: 213-220.

27. Ullah, S., Khan, J., Hayat, K., Elateeq, A.A., Salam, U., Yu, B., Ma, Y., Wang, H., Tang, Z.H., 2020, Comparative study of growth, cadmium accumulation and tolerance of three chickpea (Cicer arietinum $\mathrm{L}$.) cultivars, Plants, 9: 310.

28. Ahsan, N., Lee, S.H., Lee, D.G., Lee, H., Lee, S.W., Bahk, J.D., Lee, B.H., 2007, Physiological and protein profiles alternation of germinating rice seedlings exposed to acute cadmiumtoxicity, Comptes Rendus Biologies, 330: 735-746.

29. Jun-yu, H., Yan-fang, R., Cheng, Z., De-an, J., 2008, Effects of cadmium stress on seed germination, seedling growth and seed amylase activities in rice (Oryza sativa), Rice Science, 15 (4): 319-325.

30. Vijayaragavan, M., Prabhahar, C., Sureshkumar, J., Natarajan, A., Vijayarengan, P., Sharavanan, S., 2011, Toxic effect of cadmium on seed germination, growth and biochemical contents of cowpea (Vigna unguiculata L.) plants, International Multidisciplinary Research Journal, 1: 1-6.

31. Imran, M., Hussain, S., El-Esawi, M.A., Rana, M.S., Saleem, M.H., Riaz, M., Ashraf, U., Potcho, M.P., Duan, M., Rajput, I.A., Tang, X., 2020, Molybdenum supply alleviates the cadmium toxicity in fragrant rice by modulating oxidative stress and antioxidant gene expression, Biomolecules, 10: 1582.

32. Alyemeni, M., Abass, M., Wijaya, L., Alam, P., Ahmad, P., 2017, Contrasting tolerance among soybean genotypes subjected to different levels of cadmium stress, Pakistan Journal of Botany, 49 (3): 903-911.

33. Raza, A., Habib, M., Kakavand, S.N., Zahid, Z., Zahra, N., Sharif, R., Hasanuzzaman, M., 2020, Phytoremediation of cadmium: physiological, biochemical, and molecular mechanisms, Biology, 9: 177.

34. Kanu, A.S., Ashraf, U., Mo, Z., Sabir, S.R., Baggie, I., Charley, C.S., Tang, X., 2019, Calcium amendment improved the performance of fragrant rice and reduced metal uptake under cadmium toxicity, Environmental Science and Pollution Research, 26: 24748-24757.

35. Jiang, M., Jiang, J., Lia, S., Lia, M., Tan, Y., Song, S., Shu, Q., Huang, J., 2020, Glutamate alleviates cadmium toxicity in rice via suppressing cadmium uptake and translocation, Journal of Hazardous Materials, 384: 121319 .

\title{
COMPORTAMENTUL DE GERMINARE A SEMINȚELOR, CREȘTEREA PLANTULELOR, CARACTERISTICI MORFO-FIZIOLOGICE ȘI DE RANDAMENT ALE OREZULUI CRESCUT PE SOL ÎMBOGĂȚIT CU CADMIU
}

\author{
(Rezumat)
}

S-a efectuat un experiment pentru a investiga efectul diferitelor cantități de cadmiu (Cd) asupra germinației, morfologiei, fiziologiei și recoltei de orez. Au existat cinci tratamente: martor (fără Cd), $0.5 \mathrm{mM} \mathrm{CdCl} 2,1 \mathrm{mM} \mathrm{CdCl}$, $1.5 \mathrm{mM} \mathrm{CdCl}_{2}$ şi $2 \mathrm{mM} \mathrm{CdCl}_{2}$, cu trei repetiţii fiecare, realizate prin design-ul aleatoriu complet (RCBD). Stresul cauzat de cantitățile de cadmiu s-a tradus prin reducerea semnificativă a înălțimii plantelor și a numărului de plantule pe unitatea de suprafață, invers proporțională cu doza administrată. Cea mai mare descreștere a conținutului relativ de apă și a valorii SPAD s-a înregistrat la concentrații ale cadmiului de 1.5 mM (11 și 16\%) și 2 mM (14 și 19\%), comparativ cu martorul. Numărul de plantule pe unitatea de suprafață, numărul de panicule cu boabe pline, greutatea a 1000 de semințe, lungimea paniculului, producția de cariopse și producția de paie s-au redus semnificativ la concentrații de 44, 32, 15, 24, 37 și 45\%, comparativ cu martorul. Parametrii asociaţi germinației și plantulelor au fost înregistrați la 10 zile după germinare. Cel mai scăzut procent de germinație $(27 \%)$, indexul germinativ $(27 \%)$ și indexul de vigoare a planulei (49\%) s-au înregistrat în cazul celei mai mari concentrații de cadmiu folosite, comparativ cu martorul. Stresul cauzat de cadmiu s-a manifestat printr-un număr crescut de plantule anormale, prin reducerea lungimii rădăcinii și a tulpinilor, dar și prin greutatea lor în stare proaspătă sau uscată. Raportul rădăcină-tulpină a 
variat în funcție de cantitatea de cadmiu administrată. Astfel, se poate concluziona că o cantitate crescută de cadmiu în sol are un efect negativ asupra germinării semințelor, morfologiei, fiziologiei și recoltei de orez.

Received: 11.01.2021; Accepted: 16.06.2021. 